\title{
Return On Goodwill
}

David E. Vance, Rutgers University School of Business Camden, USA

\begin{abstract}
Goodwill represents value not recorded until a company is purchased by another company. The value of goodwill comes from intangibles such as location, superior market position or the skill and learning of management. Goodwill is the difference between the purchase price of a company and the fair value of its assets. The residual nature of goodwill makes measurement of its contribution to performance difficult. Two questions flow from this. The first is whether the contribution of goodwill is measurable. The second question is whether the contribution of goodwill varies from industry to industry. One way to measure contribution is return on assets. This study analyses 38,519 years of company operations in 48 industries and compares the return of companies with and without goodwill. For some, but not all industries, return on assets for companies with goodwill was higher that for companies without goodwill. The contributions of this study are to demonstrate whether goodwill contributes to performance and to analyze variability of performance by industry.
\end{abstract}

Keywords: Goodwill, return, rent, value, booked goodwill

\section{INTRODUCTION}

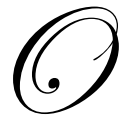

ne difficulty in measuring the return on goodwill is that goodwill is a residual. Goodwill is the difference between the purchase price of a company and the fair value of its assets. This difference is booked as an asset under authority of Financial Accounting Standards Board (FASB) Statement of Accounting Standard (SFAS) No. 141 Business Combinations (2001) and Accounting Principals Board (ABP) Opinion 16, Business Combinations (1970) prior to that.

Goodwill has historically been a significant asset on the books of US corporations and with the implementation of SFAS 141 (2001), which requires all business combinations to be treated as purchases, it will become more significant. In 2005, the 4,815 largest companies on Compustat had \$54.4 trillion of assets and \$2.3 trillion of booked goodwill or about $4.23 \%$ of total assets. In 2006, the 4,815 largest companies had $\$ 62.7$ trillion of assets and $\$ 2.4$ trillion of booked goodwill or about $3.91 \%$ of total assets.

The argument for goodwill is that acquirers pay the fair market value of firms and the difference between the purchase price and the fair market value of acquired assets represents a premium for the skills of management and other value not captured by Generally Accepted Accounting Practices (GAAP).

One characteristic of an asset is that it can generate rent which can be measured in terms of return on assets. This study analyzes the return on assets of companies with and without goodwill on an industry by industry basis and tests whether goodwill provides abnormal returns.

The contributions of this study are to demonstrate whether the impact of goodwill on company performance is measurable and to analyze variability of that impact on an industry by industry basis.

Section II of this study is a literature review. Section III presents the research questions. Section IV describes the data and methodology used. Section V presents the empirical analysis and suggestions for future research and Section VI is the conclusion. 


\section{LITERATURE REVIEW}

There is large and authoritative body of literature discussing the rational for goodwill (Barber and Strack 2005; Massoud \& Raiborn 2003; SFAS141 2001; APB16 1970; Accounting Research Bulletin (ARB) No.24 1944; California Code of Civil Procedure $\$ 1263.510(\mathrm{~b})$ ), Bourne 1888). However, not everyone agrees that goodwill represents value.

Some suggest that goodwill is simply a plug figure (Lander and Reinstein 2003; Massoud and Raiborn 2003); that it should be written off immediately (Accounting Research Study No. 10, "Accounting for Goodwill" 1968) or that it represents an overpayment (Johnson and Petrone 1998). Some suggest that goodwill is not a good theoretical fit into the definition of an asset (Samuelson 1996; Schuetze 1993; Fisher 1906). These criticisms of goodwill are inconsistent with the fact that companies pay billions of dollars for goodwill each year. A more nuanced question is whether goodwill contributes to profitability in a measurable way. If goodwill contributes to profitability as much as any other asset, that provides support for booking goodwill as an asset.

Six studies have analyzed the market's perception of whether goodwill generates rent by using market capitalization as the dependent variable and goodwill and a variety of other measures as independent variables (Begley, Chamberlain and Yinghua 2006, Jennings, Robinson, Thompson and Duvall 1996, McCarthy and Schneider 1995, Wang 1995, 1993 and Chauvin and Hirschey 1994). These studies found that goodwill was valued by the markets at least as much as other assets except in manufacturing companies. This is consistent with the argument of Barber and Strack (2005) that performance depends more on people than assets. Each of these studies was limited to companies with goodwill. Samples sizes and the results of these six studies are summarized in Table 1 Prior empirical findings.

Table 1: Prior Empirical Research

The number of companies in each study varied from year to year. The common denominator is the total number of years of company operations considered in each study.

\begin{tabular}{|c|c|c|c|}
\hline Study & $\begin{array}{c}\text { Years of } \\
\text { operations }\end{array}$ & Methodology & Finding \\
\hline $\begin{array}{l}\text { Begley, Chamberlain } \\
\text { and Li } 2006\end{array}$ & 1,865 & $\begin{array}{l}\text { Regression of loan and deposit levels, new loans } \\
\text { and new deposits, non-performing loans and fee } \\
\text { income against goodwill defined as the difference } \\
\text { between equity and market value. Limited to } \\
\text { banks. }\end{array}$ & $\begin{array}{l}\text { Banks are consistently valued } \\
\text { higher than their underlying } \\
\text { assets which suggest the } \\
\text { difference is goodwill. }\end{array}$ \\
\hline $\begin{array}{l}\text { Jennings, Robinson, } \\
\text { Thompson and Duvall } \\
1996\end{array}$ & 259 & $\begin{array}{l}\text { Regression of plant, property and equipment, } \\
\text { goodwill, other assets and liabilities against the } \\
\text { market value. Limited to non-depository firms } \\
\text { with goodwill. }\end{array}$ & $\begin{array}{l}\text { Markets consistently value } \\
\text { goodwill higher than either } \\
\text { plant, property and equipment } \\
\text { or other assets. }\end{array}$ \\
\hline $\begin{array}{l}\text { McCarthy and } \\
\text { Schneider } 1995\end{array}$ & 6,216 & $\begin{array}{l}\text { Regressions of goodwill, other assets, liabilities, } \\
\text { other assets and income against market value. } \\
\text { Limited to firms with goodwill. }\end{array}$ & $\begin{array}{l}\text { Markets consistently value } \\
\text { goodwill at least as much as } \\
\text { other assets. }\end{array}$ \\
\hline Wang 1995 & 3,728 & $\begin{array}{l}\text { Regressions of goodwill, other assets and } \\
\text { liabilities against market value. Limited to firms } \\
\text { with goodwill. }\end{array}$ & $\begin{array}{l}\text { Markets consistently value } \\
\text { goodwill more than other } \\
\text { assets. }\end{array}$ \\
\hline $\begin{array}{l}\text { Chauvin and Hirschey } \\
1994\end{array}$ & 2,693 & $\begin{array}{l}\text { Recursive regression of goodwill, net income, } \\
\text { advertising, R\&D expenditures, market share, } \\
\text { intangible assets, tangible assets, leverage, sales } \\
\text { growth and Beta against market value. Limited to } \\
\text { firms with goodwill. }\end{array}$ & $\begin{array}{l}\text { Goodwill was valued for non- } \\
\text { manufacturing companies, but } \\
\text { not for manufacturing } \\
\text { companies. }\end{array}$ \\
\hline Wang 1993 & 136 & $\begin{array}{l}\text { Regressions of goodwill, non-goodwill assets and } \\
\text { liabilities against market value. Limited to service } \\
\text { firms with goodwill. }\end{array}$ & $\begin{array}{l}\text { Goodwill assets are } \\
\text { understated relative to their } \\
\text { theoretical value. }\end{array}$ \\
\hline
\end{tabular}


The studies in Table 1 embrace the broadest possible definition of goodwill which includes both booked and unbooked goodwill, where unbooked goodwill is assumed to be the difference between recorded assets and market value. This study examines the subset of goodwill that is booked pursuant to SFAS141 (2001) and its predecessor APB 16 (1970). A critical question is whether goodwill generates rents equal to, greater than or less than other assets. Previous studies of goodwill raise some interesting questions. For example, does the rent generating power of goodwill vary from industry to industry? One contribution of this study is to answer that question on a much more granular level than prior studies.

\section{RESEARCH QUESTIONS}

The residual nature of goodwill makes measurement of its contribution difficult. If goodwill is a rent generating asset then companies with goodwill should produce a return on assets comparable to companies without booked goodwill. Return on assets (ROA) is defined in this study as operating income before depreciation and amortization scaled by average assets.

Some industries, like coal mining, rely heavily on physical assets whereas other industries, like business services, rely on intellectual capital. If goodwill represents the skill and learning of employees and management, it is possible that goodwill generates more rent in industries that rely on knowledge than industries that rely on assets. This is consistent with the findings research cited in Table 1 and leads to research question one.

Is there a statistically significant difference in the ROA of companies with booked goodwill and those without booked goodwill on an industry by industry. Stated algebraically hypothesis $\mathrm{H}_{0}$ is:

$\mathrm{ROA}_{\mathrm{GWi}}=\mathrm{ROA}_{\mathrm{NGWi}}$

where $\mathrm{ROA}_{\mathrm{GW}}$ is the return on assets of companies with goodwill in industry $\mathrm{i}$ and $\mathrm{ROA}_{\mathrm{NGWi}}$ is the return on assets of companies with no goodwill in industry $i$.

In this study, a company is considered to have goodwill if goodwill comprises one percent or more of its assets. Companies for which goodwill represents less than one percent of assets are considered not to have goodwill. This raises the possibility that companies with no goodwill are being compared to companies with slightly more than one percent goodwill. To place the issue of whether goodwill generates rent in bold relief, the ROA of companies without goodwill are also compared to companies in which goodwill represents at least twenty percent of assets. These are called high goodwill companies. This leads to the research question two.

Is there a statistically significant difference between the ROA of companies with no booked goodwill and those with high booked goodwill on an industry by industry basis? Stated algebraically hypothesis $\mathrm{H}_{1}$ is:

$\mathrm{ROA}_{\mathrm{HGWi}}=\mathrm{ROA}_{\mathrm{NGWi}}$

where $\mathrm{ROA}_{\mathrm{HGW}}$ is the return on assets of companies with high goodwill in industry $i$ and $\mathrm{ROA}_{\mathrm{NGWi}}$ is the return on assets of companies with no goodwill in industry i.

\section{METHODOLOGY}

\section{Data Source}

To explore the questions raised by the literature and this paper, return on assets was analyzed for the ten year period 1995 to 2004. Firms which began each year with at least $\$ 20$ million of assets, stock price of at least $\$ 1$, and sales of at least $\$ 5$ million were selected from the Compustat North American database. Firms with less than \$20 million in assets were eliminated so that numerous small firms without goodwill would not distort statistical analyses through dint of numbers. Sales of $\$ 5$ million was selected as a minimum threshold for an active company. Firms with a stock price of less than $\$ 1$ were eliminated to remove more speculative companies. Companies that had sufficient assets, sales and stock price to be selected one year did not necessarily qualify for selection in all ten years 
of this study. Some companies merged, went out of business or fell below the selection threshold. For example, a company could be unselected in one year because it did not meet minimum criteria, classified as a company without goodwill for five years and a company with goodwill for four years. To maximize the data available for this study, companies were selected and their performance in terms of ROA was evaluated on a year by year basis, with each year being a data point. These data points were aggregated by industry and then classified by the percentage of goodwill on their balance sheet in a particular year.

Firms with incomplete information were also eliminated from the sample. There were 2,652 firms that met the foregoing criteria in 1995 and 4,985 firms which met these criteria in 2004. See Table 2 Overview of study population. In total, this study analyzes some 38,519 years of company operating experience.

Table 2: Overview of Study Population

Publicly traded companies listed on Compustat with at least $\$ 20$ million in assets, a share price of $\$ 1$ and $\$ 5$ million in sales were selected for this study to eliminate smaller, more speculative and inactive companies. Return on Assets (ROA) is operating income before depreciation and amortization divided by average assets. Dollars are in millions.

\begin{tabular}{cccccccc}
\hline Year & $\begin{array}{c}\text { Companies } \\
\text { selected }\end{array}$ & $\begin{array}{c}\text { Total Assets } \\
\text { beginning } \\
\text { of year }\end{array}$ & $\begin{array}{c}\text { Average } \\
\text { beginning } \\
\text { assets }\end{array}$ & $\begin{array}{c}\text { Total Goodwill } \\
\text { beginning } \\
\text { of year }\end{array}$ & $\begin{array}{c}\text { Average } \\
\text { beginning } \\
\text { goodwill }\end{array}$ & $\begin{array}{c}\text { Beginning of } \\
\text { year goodwill } \\
\text { as \% of assets }\end{array}$ & $\begin{array}{c}\text { Average } \\
\text { ROA }\end{array}$ \\
\hline 1995 & 2,652 & $10,634,953$ & 4,010 & 156,674 & 59 & $1.47 \%$ & $13.52 \%$ \\
1996 & 2,986 & $12,996,179$ & 4,352 & 172,546 & 58 & $1.33 \%$ & $13.06 \%$ \\
1997 & 3,390 & $15,111,693$ & 4,458 & 242,881 & 72 & $1.61 \%$ & $12.73 \%$ \\
1998 & 3,640 & $16,790,999$ & 4,613 & 325,667 & 89 & $1.94 \%$ & $11.54 \%$ \\
1999 & 3,925 & $20,981,758$ & 5,346 & 464,872 & 118 & $2.22 \%$ & $10.95 \%$ \\
2000 & 4,173 & $25,524,547$ & 6,117 & 674,422 & 162 & $2.64 \%$ & $10.24 \%$ \\
2001 & 4,385 & $31,676,147$ & 7,224 & $1,045,970$ & 239 & $3.30 \%$ & $7.68 \%$ \\
2002 & 4,420 & $37,306,619$ & 8,440 & $1,129,075$ & 255 & $3.03 \%$ & $8.62 \%$ \\
2003 & 4,594 & $42,014,932$ & 9,146 & $1,648,537$ & 359 & $3.92 \%$ & $9.38 \%$ \\
2004 & 4,354 & $38,525,819$ & 8,848 & $1,695,474$ & 389 & $4.40 \%$ & $9.91 \%$ \\
\hline
\end{tabular}

\section{Variables}

The dependent variable tested in this study is return on assets (ROA) defined as operating income before depreciation and amortization scaled by average assets. The independent variables in this study include: industry, whether or not a company has goodwill, and whether a company is a high goodwill company.

The mean and standard deviation of ROA were computed by industry for companies with goodwill, without goodwill and with high goodwill. These measures were then tested for statistically significant differences.

This study uses the Fama and French (1997) classification system which assigns four digit standard industrial codes (SIC) to forty eight industries. A SIC / industry cross reference table is provided as Appendix A.

\section{EMPIRICAL ANALYSIS}

\section{Goodwill Companies vs. Non-Goodwill Companies}

The Coal, Gold, and Smoke industries were eliminated from the study because, over a ten year period, they had less than twenty years of operations with goodwill, the minimum number deemed necessary to draw statistically reliable conclusions. Of the remaining forty five industries, companies without goodwill outperformed companies with goodwill in six industries on a statistically significant basis. Such findings tend to support the notion that goodwill is simply a plug figure rather than an asset as claimed by SFAS 141 (2001). However, in twenty one industries, there was no statistically significant difference in the performance of companies with and without goodwill. This finding tends to support the assumption underlying SFAS 141 (2001) that goodwill represents value not captured by traditional accounting means, but which is recognized in the price paid for purchased firms. The more surprising finding is that companies with goodwill outperformed those without goodwill in eighteen of forty 
five industries. This indicates that goodwill provides a return superior return to that of traditional assets in many industries and is consistent with the argument of Barber and Strack (2005) that performance depends more on people than assets. The performance of companies with and without goodwill by industry is provided in Table 3 Performance analysis.

The data answer research question one in the affirmative by demonstrating the rent generating power of goodwill varies from industry to industry. Therefore we must reject $\mathrm{H}_{0}$ for some, but not all industries. See Table 4 Summary of industry results.

\section{High Goodwill Companies vs. Non-Goodwill Companies}

While companies with goodwill perform at least as well as companies without goodwill in thirty nine of forty five industries, it is reasonable to ask whether a firm conclusion can be drawn by comparing companies with less than one percent goodwill to companies with slightly more than one percent goodwill. Research question two seeks to address this by comparing the performance of high goodwill companies, that is those with twenty percent or more of their assets in goodwill, to companies without booked goodwill. Ten industries were eliminated from this analysis (Agric, Banks, Beer, Coal, Gold, Guns, Mines, Smoke, Soda and Txtls) because each had less than twenty years of operating history with high goodwill companies. Of the remaining thirty eight industries, the data show that in six industries, high booked goodwill companies underperformed companies with no booked goodwill by statistically significant margins; in twenty industries there is no statistically significant difference between companies with high booked goodwill and those without booked goodwill; and in twelve industries companies with high booked goodwill outperformed companies with no booked goodwill by a statistically significant margin. Table 3 provides the performance analysis and statistical details of each industry and Table 4 provides a summary of industry results.

The answer to research question two, which asks whether there is a difference in the rent generating power of high booked goodwill companies and companies without booked goodwill on an industry by industry basis, is that there is a statistically significant difference for some industries. We must therefore reject hypothesis $\mathrm{H}_{1}$ for some, but not all industries. However, the fact that thirty two of the thirty eight industries with high booked goodwill performed as well as, or better than, companies without booked goodwill tends to refute the theory that goodwill is simply a plug number and not a rent generating asset.

\section{Questions for Further Research}

As robust as these findings seem, they raise several questions for further research. For example, is the guidance provided by FASB 141 (2001) is too broad? Perhaps it should be revised to include tests to determine whether goodwill is likely to generate promised benefits as suggested by SFAC 6 (1985). One such test might be whether goodwill has historically generated rent in a particular industry.

Even in industries where companies with booked goodwill under perform those without booked goodwill we cannot necessarily conclude that all booked goodwill is worthless. Some fraction of it, perhaps that fraction representing an overpayment, may be worthless. Distinguishing rent generating goodwill from non-rent generating goodwill presents a question for further research.

One theory advanced for the value of booked goodwill is that the skill and learning of a company's management is a key value driver. If so, perhaps goodwill is simply a marker for some set of superior management behaviors. A future line of research might concentrate on identifying such behaviors and determining whether there is a better means of measuring such value than by booking goodwill generated through a business combination. 
Table 3: Performance Analysis

All companies reported on Compustat from 1995 to 2004 with at least $\$ 20$ million in assets, a stock price of $\$ 1$ and sales of $\$ 5$ million were selected for this study. The result was some 38,519 years of operating history. Return on assets (ROA) is defined as operating income before depreciation and amortization scaled by average assets. Companies were classified by industry using the Fama and French (1997) system. Companies with goodwill had at least one percent of their assets in goodwill. Companies without goodwill had less than one percent of their assets in goodwill. High goodwill companies where those with at least twenty percent of their assets in goodwill. High goodwill companies are a lesser included set of companies with goodwill. The winner column indicates whether companies with goodwill (GW) outperformed those without goodwill (NoGW) or whether no goodwill companies outperformed those with goodwill. Entries in italics are industries for which there were less than twenty operating years with goodwill or high goodwill respectively, so no conclusions were draw about rent generation. They are included in this table for completeness only.

\begin{tabular}{|c|c|c|c|c|c|c|c|c|c|c|c|c|c|c|c|c|c|}
\hline \multirow[b]{2}{*}{ Industry } & \multicolumn{3}{|c|}{ Cos with goodwill } & \multicolumn{3}{|c|}{ Cos with no goodwill } & \multicolumn{3}{|c|}{ Cos with high goodwill } & \multirow{2}{*}{\multicolumn{3}{|c|}{$\begin{array}{l}\text { Goodwill v. no goodwill } \\
\text { t-stat } \quad \text { p-value }\end{array}$}} & \multirow[b]{2}{*}{ winner } & \multicolumn{4}{|c|}{ High goodwill y no goodwill } \\
\hline & $\mathbf{n}$ & $\begin{array}{l}\text { Mean } \\
\text { ROA }\end{array}$ & $\begin{array}{l}\text { Std.dev. } \\
\text { ROA }\end{array}$ & $\mathbf{n}$ & $\begin{array}{l}\text { Mean } \\
\text { ROA }\end{array}$ & $\begin{array}{l}\text { Std.dev } \\
\text { ROA }\end{array}$ & $\mathbf{n}$ & $\begin{array}{l}\text { Mean } \\
\text { ROA }\end{array}$ & $\begin{array}{l}\text { Std.Dev. } \\
\text { ROA }\end{array}$ & & & & & $\begin{array}{l}\text { High go } \\
\text { t-stat }\end{array}$ & $\begin{array}{c}\text { dwill v. } n \\
\text { p-value }\end{array}$ & good & $\begin{array}{l}\text { vill } \\
\text { winner }\end{array}$ \\
\hline Aero & 105 & $13.8 \%$ & $5.2 \%$ & 38 & $13.60 \%$ & $7.31 \%$ & 33 & $14.15 \%$ & $3.40 \%$ & 0.1318 & 0.4483 & & & 0.4150 & 0.3372 & & \\
\hline Agric & 53 & $13.3 \%$ & $7.6 \%$ & 72 & $9.21 \%$ & $7.15 \%$ & 15 & $14.70 \%$ & $5.39 \%$ & 3.0760 & 0.0010 & $* * *$ & GW & 3.3745 & 0.0004 & $* * *$ & $G W$ \\
\hline Autos & 324 & $13.2 \%$ & $8.6 \%$ & 302 & $14.77 \%$ & $10.20 \%$ & 91 & $13.33 \%$ & $10.96 \%$ & -2.1293 & 0.0166 & $* *$ & NoGW & -1.1161 & 0.1314 & & \\
\hline Banks & 77 & $10.6 \%$ & $9.5 \%$ & 5069 & $3.00 \%$ & $2.87 \%$ & 16 & $12.68 \%$ & $8.17 \%$ & 6.9543 & 0.0000 & $* * *$ & GW & 4.7384 & 0.0000 & $* * *$ & $G W$ \\
\hline Beer & 84 & $16.0 \%$ & $7.3 \%$ & 84 & $14.27 \%$ & $7.51 \%$ & 7 & $14.83 \%$ & $5.45 \%$ & 1.5206 & 0.0643 & $*$ & GW & 0.2526 & 0.4013 & & \\
\hline BldMt & 339 & $15.5 \%$ & $7.1 \%$ & 332 & $15.53 \%$ & $8.75 \%$ & 69 & $14.84 \%$ & $6.60 \%$ & 0.0000 & 0.5000 & & & -0.7432 & 0.2296 & & \\
\hline Books & 184 & $15.8 \%$ & $11.6 \%$ & 152 & $16.86 \%$ & $11.35 \%$ & 125 & $14.86 \%$ & $6.60 \%$ & -0.8765 & 0.1894 & & & -1.8288 & 0.0336 & $* *$ & NoGW \\
\hline Boxes & 96 & $15.5 \%$ & $5.5 \%$ & 48 & $14.28 \%$ & $4.63 \%$ & 30 & $12.56 \%$ & $2.33 \%$ & 1.4251 & 0.0764 & $*$ & $\mathrm{GW}$ & -2.1712 & 0.0150 & $* *$ & NoGW \\
\hline BusSv & 1828 & $12.2 \%$ & $15.9 \%$ & 1921 & $6.56 \%$ & $22.50 \%$ & 628 & $11.19 \%$ & $12.55 \%$ & 8.9388 & 0.0000 & $* * *$ & $\mathrm{GW}$ & 6.4559 & 0.0000 & $* * *$ & $\mathrm{GW}$ \\
\hline Chem & 389 & $12.6 \%$ & $8.2 \%$ & 344 & $15.45 \%$ & $9.54 \%$ & 80 & $14.55 \%$ & $9.69 \%$ & -4.2548 & 0.0000 & $* * *$ & NoGW & -0.7505 & 0.2260 & & \\
\hline Chips & 815 & $9.2 \%$ & $13.0 \%$ & 1427 & $9.70 \%$ & $16.98 \%$ & 165 & $6.19 \%$ & $11.77 \%$ & -0.8127 & 0.3090 & & & -3.4391 & 0.0003 & $* * *$ & NoGW \\
\hline Clths & 241 & $14.7 \%$ & $9.9 \%$ & 308 & $15.42 \%$ & $12.79 \%$ & 35 & $14.96 \%$ & $9.01 \%$ & -0.7348 & 0.2327 & & & -0.2725 & 0.3936 & & \\
\hline Cnstr & 238 & $12.0 \%$ & $6.9 \%$ & 175 & $12.33 \%$ & $10.46 \%$ & 55 & $10.18 \%$ & $6.03 \%$ & -0.3189 & 0.3745 & & & -1.8957 & 0.0287 & $* *$ & NoGW \\
\hline Coal & 1 & $24.8 \%$ & $0.0 \%$ & 45 & $11.67 \%$ & $11.23 \%$ & 1 & $24.78 \%$ & $0.00 \%$ & 7.8312 & 0.0000 & $* * *$ & $G W$ & 7.8312 & 0.0000 & $* * *$ & $G W$ \\
\hline Comps & 428 & $7.5 \%$ & $12.1 \%$ & 912 & $5.92 \%$ & $20.02 \%$ & 92 & $6.94 \%$ & $11.82 \%$ & 1.7514 & 0.0401 & $* *$ & GW & 0.7289 & 0.2327 & & \\
\hline Drugs & 419 & $10.0 \%$ & $18.1 \%$ & 922 & $-3.70 \%$ & $26.19 \%$ & 93 & $7.32 \%$ & $11.87 \%$ & 11.0604 & 0.0000 & $* * *$ & GW & 7.3321 & 0.0000 & $* * *$ & GW \\
\hline ElcEq & 297 & $12.9 \%$ & $10.2 \%$ & 275 & $8.13 \%$ & $20.00 \%$ & 93 & $12.31 \%$ & $8.41 \%$ & 3.5594 & 0.0000 & $* * *$ & GW & 2.8086 & 0.0025 & $* * *$ & GW \\
\hline Enrgy & 287 & $15.7 \%$ & $7.7 \%$ & 928 & $17.72 \%$ & $13.05 \%$ & 33 & $16.33 \%$ & $5.76 \%$ & -3.2777 & 0.0005 & $* * *$ & NoGW & -1.2748 & 0.1020 & & \\
\hline FabPr & 65 & $13.5 \%$ & $6.8 \%$ & 67 & $12.70 \%$ & $6.94 \%$ & 30 & $12.31 \%$ & $5.69 \%$ & 0.6675 & 0.2514 & & & -0.2908 & 0.3859 & & \\
\hline Fin & 200 & $18.6 \%$ & $16.2 \%$ & 856 & $14.16 \%$ & $24.35 \%$ & 70 & $21.07 \%$ & $14.54 \%$ & 3.1357 & 0.0008 & $* * *$ & GW & 3.5861 & 0.0000 & $* * *$ & GW \\
\hline
\end{tabular}

*** Statistically significant at the .01 level

** Statistically significant at the .05 level

* Statistically significant at the .10 leve 
Table 3: Performance Analysis - continued

\begin{tabular}{|c|c|c|c|c|c|c|c|c|c|c|c|c|c|c|c|c|c|}
\hline \multirow[b]{2}{*}{ Industry } & \multicolumn{3}{|c|}{ Cos with goodwill } & \multicolumn{3}{|c|}{ Cos with no goodwill } & \multicolumn{3}{|c|}{ Cos with high goodwill } & \multirow{2}{*}{\multicolumn{3}{|c|}{$\begin{array}{l}\text { Goodwill v. no goodwill } \\
\text { t-stat } \quad \text { p-value }\end{array}$}} & & \multirow{2}{*}{\multicolumn{4}{|c|}{$\begin{array}{l}\text { High goodwill v. no goodwill } \\
\text { t-stat p-value }\end{array}$}} \\
\hline & $\mathbf{n}$ & $\begin{array}{l}\text { Mean } \\
\text { ROA }\end{array}$ & $\begin{array}{l}\text { Std.dev. } \\
\text { ROA }\end{array}$ & n & $\begin{array}{l}\text { Mean } \\
\text { ROA }\end{array}$ & $\begin{array}{l}\text { Std.dev } \\
\text { ROA }\end{array}$ & $\mathbf{n}$ & $\begin{array}{l}\text { Mean } \\
\text { ROA }\end{array}$ & $\begin{array}{l}\text { Std.Dev. } \\
\text { ROA }\end{array}$ & & & & & & & & \\
\hline Food & 191 & $16.0 \%$ & $7.9 \%$ & 336 & $14.48 \%$ & $9.87 \%$ & 57 & $15.54 \%$ & $5.26 \%$ & 1.9216 & 0.0274 & $* *$ & GW & 1.2038 & 0.1151 & & \\
\hline Fun & 192 & $15.7 \%$ & $11.4 \%$ & 248 & $15.76 \%$ & $12.09 \%$ & 39 & $17.29 \%$ & $11.70 \%$ & -0.0712 & 0.4960 & & & 0.7557 & 0.2236 & & \\
\hline Gold & 11 & $9.6 \%$ & $8.6 \%$ & 180 & $5.12 \%$ & $14.28 \%$ & 2 & $13.74 \%$ & $3.64 \%$ & 1.6087 & 0.0537 & $*$ & $G W$ & 3.0949 & 0.0010 & $* * *$ & $G W$ \\
\hline Guns & 46 & $10.7 \%$ & $6.5 \%$ & 22 & $18.33 \%$ & $10.44 \%$ & 18 & $8.98 \%$ & $4.98 \%$ & -3.1714 & 0.0011 & $* * *$ & NoGW & -3.7157 & 0.0000 & $* * *$ & $N o G W$ \\
\hline Hlth & 361 & $16.1 \%$ & $11.9 \%$ & 194 & $13.64 \%$ & $15.22 \%$ & 196 & $18.00 \%$ & $10.57 \%$ & 1.9154 & 0.0274 & $* *$ & GW & 3.2827 & 0.0005 & $* * *$ & GW \\
\hline Hshld & 264 & $15.6 \%$ & $10.2 \%$ & 340 & $15.54 \%$ & $8.86 \%$ & 61 & $16.38 \%$ & $11.01 \%$ & 0.1140 & 0.4562 & & & 0.5640 & 0.2877 & & \\
\hline Insur & 460 & $6.7 \%$ & $8.2 \%$ & 844 & $6.19 \%$ & $8.01 \%$ & 66 & $13.34 \%$ & $7.94 \%$ & 1.1023 & 0.1539 & & & 7.0409 & 0.0000 & $* * *$ & GW \\
\hline LabEq & 308 & $10.5 \%$ & $11.8 \%$ & 409 & $9.35 \%$ & $15.56 \%$ & 78 & $13.57 \%$ & $12.13 \%$ & 1.1063 & 0.1446 & & & 2.6806 & 0.0037 & $* * *$ & GW \\
\hline Mach & 689 & $12.7 \%$ & $8.3 \%$ & 572 & $11.99 \%$ & $13.58 \%$ & 200 & $12.81 \%$ & $5.67 \%$ & 1.0454 & 0.1469 & & & 1.1797 & 0.1190 & & \\
\hline Meals & 246 & $17.4 \%$ & $7.8 \%$ & 414 & $14.87 \%$ & $8.81 \%$ & 27 & $15.94 \%$ & $5.67 \%$ & 3.8481 & 0.0000 & $* * *$ & $\mathrm{GW}$ & 0.9114 & 0.1814 & & \\
\hline MedEq & 417 & $13.2 \%$ & $15.0 \%$ & 440 & $5.65 \%$ & $20.17 \%$ & 168 & $13.71 \%$ & $11.95 \%$ & 6.2554 & 0.0000 & $* * *$ & GW & 6.0504 & 0.0000 & $* * *$ & GW \\
\hline Mines & 54 & $15.4 \%$ & $6.1 \%$ & 110 & $15.05 \%$ & $10.05 \%$ & 6 & $16.54 \%$ & $2.76 \%$ & 0.3087 & 0.3483 & & & 1.0074 & 0.1562 & & \\
\hline Misc & 164 & $12.2 \%$ & $9.1 \%$ & 97 & $12.91 \%$ & $14.98 \%$ & 39 & $12.66 \%$ & $7.98 \%$ & -0.4347 & 0.3336 & & & -0.1258 & 0.4483 & & \\
\hline Paper & 257 & $14.8 \%$ & $7.4 \%$ & 246 & $13.67 \%$ & $7.60 \%$ & 73 & $13.16 \%$ & $4.41 \%$ & 1.6340 & 0.0516 & $*$ & GW & -0.7204 & 0.2358 & & \\
\hline PerSv & 206 & $15.6 \%$ & $11.5 \%$ & 146 & $17.12 \%$ & $13.30 \%$ & 92 & $15.70 \%$ & $11.29 \%$ & -1.1399 & 0.1271 & & & -0.8811 & 0.1894 & & \\
\hline Retail & 747 & $14.1 \%$ & $9.9 \%$ & 1256 & $16.21 \%$ & $11.74 \%$ & 150 & $12.61 \%$ & $9.11 \%$ & -4.3417 & 0.0000 & $* * *$ & NoGW & -4.4212 & 0.0000 & $* * *$ & NoGW \\
\hline RlEst & 64 & $11.8 \%$ & $9.9 \%$ & 236 & $8.04 \%$ & $8.61 \%$ & 22 & $18.01 \%$ & $9.12 \%$ & 2.7608 & 0.0029 & $* * *$ & GW & 4.9270 & 0.0000 & $* * *$ & GW \\
\hline Rubbr & 194 & $14.8 \%$ & $5.9 \%$ & 135 & $13.26 \%$ & $8.79 \%$ & 58 & $13.60 \%$ & $4.13 \%$ & 1.7769 & 0.0384 & $* *$ & GW & 0.3653 & 0.3557 & & \\
\hline Ships & 39 & $13.2 \%$ & $11.2 \%$ & 41 & $9.90 \%$ & $8.59 \%$ & 18 & $13.45 \%$ & $6.01 \%$ & 1.4709 & 0.0708 & $*$ & GW & 1.8196 & 0.0287 & $* *$ & GW \\
\hline Smoke & 15 & $21.3 \%$ & $3.9 \%$ & 47 & $27.86 \%$ & $2.79 \%$ & 12 & $21.74 \%$ & $4.23 \%$ & -5.9689 & 0.0000 & $* * *$ & $N o G W$ & -4.7548 & 0.0000 & $* * *$ & $N o G W$ \\
\hline Soda & 48 & $15.9 \%$ & $6.7 \%$ & 51 & $14.15 \%$ & $8.77 \%$ & 5 & $12.81 \%$ & $2.71 \%$ & 1.1362 & 0.1271 & & & -0.7766 & 0.2177 & & \\
\hline Steel & 285 & $13.3 \%$ & $7.2 \%$ & 373 & $11.18 \%$ & $9.44 \%$ & 43 & $14.64 \%$ & $6.94 \%$ & 3.2989 & 0.0005 & $* * *$ & $\mathrm{GW}$ & 2.9680 & 0.0015 & $* * *$ & GW \\
\hline Telcm & 592 & $11.6 \%$ & $11.0 \%$ & 850 & $11.21 \%$ & $15.49 \%$ & 173 & $10.73 \%$ & $9.68 \%$ & 0.6014 & 0.2743 & & & -0.5288 & 0.2981 & & \\
\hline Toys & 129 & $14.1 \%$ & $7.8 \%$ & 139 & $14.54 \%$ & $19.40 \%$ & 29 & $13.16 \%$ & $5.56 \%$ & -0.2693 & 0.3936 & & & -0.7104 & 0.2389 & & \\
\hline Trans & 423 & $13.7 \%$ & $8.0 \%$ & 676 & $13.60 \%$ & $9.40 \%$ & 82 & $10.76 \%$ & $9.60 \%$ & 0.2629 & 0.3974 & & & -2.5355 & 0.0055 & $* * *$ & NoGW \\
\hline Txtls & 83 & $12.8 \%$ & $8.6 \%$ & 83 & $14.85 \%$ & $11.18 \%$ & 18 & $9.71 \%$ & $10.31 \%$ & -1.3393 & 0.0918 & $*$ & NoGW & -1.8881 & 0.0294 & $* *$ & NoGW \\
\hline Util & 152 & $10.9 \%$ & $8.2 \%$ & 1387 & $10.78 \%$ & $4.02 \%$ & 69 & $12.53 \%$ & $9.00 \%$ & 0.1044 & 0.4602 & & & 1.6072 & 0.0537 & $*$ & GW \\
\hline Whlsl & 712 & $11.1 \%$ & $7.8 \%$ & 551 & $10.85 \%$ & $10.71 \%$ & 157 & $11.62 \%$ & $7.39 \%$ & 0.3695 & 0.3520 & & & 1.0326 & 0.1515 & & \\
\hline
\end{tabular}

*** Statistically significant at the .01 level

** Statistically significant at the .05 level

* Statistically significant at the .10 level 
Table 4 Summary of industry results

This table summarizes whether goodwill generates rent equal to or greater than other assets on an industry by industry basis. Companies with goodwill had at least one percent goodwill among their assets. Companies without goodwill had less than one percent goodwill. High goodwill companies, a subset of companies with goodwill, had at least twenty percent of assets in goodwill.

\begin{tabular}{|c|c|c|c|c|}
\hline \multirow[b]{2}{*}{ Condition } & \multicolumn{2}{|c|}{ 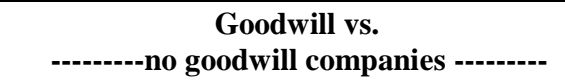 } & \multicolumn{2}{|c|}{$\begin{array}{l}\text { High goodwill vs. } \\
\text {--no goodwill companies--..-.-. }\end{array}$} \\
\hline & Industries & n & Industries & $\mathbf{n}$ \\
\hline $\begin{array}{l}\text { Industries excluded because of } \\
\text { insufficient data. }\end{array}$ & Coal, Gold, Smoke & 3 & $\begin{array}{l}\text { Agric, Banks, Beer, Coal, Gold, } \\
\text { Guns, Mines, Smoke, Soda \& } \\
\text { Txtls }\end{array}$ & 10 \\
\hline $\begin{array}{l}\text { Industries in which companies } \\
\text { without goodwill outperform } \\
\text { those with goodwill. }\end{array}$ & $\begin{array}{l}\text { Autos, Chem, Enrgy, Guns, Retail \& } \\
\text { Txtls }\end{array}$ & 6 & $\begin{array}{l}\text { Books, Boxes, Chips, Cnstr, } \\
\text { Retail \& Trans }\end{array}$ & 6 \\
\hline $\begin{array}{l}\text { Industries in which there is no } \\
\text { statistically significant difference } \\
\text { in the performance of companies } \\
\text { with and without goodwill. }\end{array}$ & $\begin{array}{l}\text { Aero, BldMt, Books, Chips, Clths, } \\
\text { Cnstr, FabPr, Fun, Hshld, Insur, } \\
\text { LabEq, Mach, Mines, Misc, PerSv, } \\
\text { Soda, Telcm, Toys, Trans, Util } \\
\text { \&Whlsl }\end{array}$ & 21 & $\begin{array}{l}\text { Aero, Autos, BldMt, Chem, } \\
\text { Clths, Comps, Enrgy, FabPr, } \\
\text { Food, Fun, Hshld, Mach, Meals, } \\
\text { Misc, Paper, PerSv, Rubbr, } \\
\text { Telcm, Toys \& Whlsl }\end{array}$ & 20 \\
\hline $\begin{array}{l}\text { Industries in which companies } \\
\text { with goodwill outperform those } \\
\text { without goodwill. }\end{array}$ & $\begin{array}{l}\text { Agric, Banks, Beer, Boxes, BusSv, } \\
\text { Comps, Drugs, ElcEq, Fin, Food, } \\
\text { Hlth, Meals, MedEq, Paper, RlEst, } \\
\text { Rubbr, Ships \& Steel } \\
\quad \text { Totals }\end{array}$ & 18 & $\begin{array}{l}\text { BusSv, Drugs, ElcEq, Fin, Hlth, } \\
\text { Insur, LabEq, MedEq, RlEst, } \\
\text { Ships, Steel \& Util }\end{array}$ & 12 \\
\hline
\end{tabular}

\section{CONCLUSION}

The results of this study broadly support the implicit assumption underlying FASB 141 (2001) that goodwill is a rent generating asset. While companies with booked goodwill under perform in a few industries, companies with goodwill performed as least as well as companies without goodwill in thirty nine of the forty five industries or about $87 \%$. To determine whether this phenomenon was the result of comparing firms with no goodwill to those with slightly more than one percent goodwill, a second analysis compared the performance of companies with no goodwill to those with $20 \%$ or more of their assets in goodwill. The data show that companies with high goodwill generate a return on assets at least as great as that of non-goodwill companies in thirty two of thirty eight industries or about $84 \%$ of the industries analyzed.

Even though goodwill represents a residual value, the difference between the purchase price of a company and the fair value of its assets, its effect can be measured in company returns. This effect varies from industry to industry. Yet there are still many unanswered questions about the nature and economic impact of goodwill. These questions await some the intrepid researcher to probe goodwill further.

\section{ACKNOWLEDGEMENT}

This paper draws heavily on Compustat data in the WRDS data base service. Access to this data base service is funded in part by the David Whitcomb Center for Research in

Financial Services. I would like to thank Dr. Ivo Jansen, Assistant Professor of Accounting, Rutgers University School of Business Camden for his comments and suggestions.

\section{AUTHOR INFORMATION}

David E. Vance, JD, MBA, CPA is a former trial attorney, corporate controller and CFO. He has written four books Financial Analysis and Decision Making, McGraw-Hill 2003, republished in Chinese 2004, Raising Capital, Springer 2005, Corporate Restructuring, Springer 2009 and Ratios for Analysis \& Control, and Profit Planning, Global Professional Publishing, 2009. He teaches Corporate Restructuring; Raising Capital; Tax and Commercial Business Law in the Rutgers University School of Business MBA program at Camden. 


\section{REFERENCES}

1. _ _ Accounting Research Bulletin (ARB) No. 24 1944. "Accounting for Intangible Assets," Dec.

2. _ - Accounting Research Study (ARS) No. 10. 1968 "Accounting for Goodwill."

3. _ Accounting Principals Board (APB) Opinion No. 16. 1970. "Business Combinations"

4. $\quad$ Barber, F. and R. Strack. Harvard Business Review June 2005, Vol.83. Iss. 6. 80-91.

5. Begley, J., S. L. Chamberlain and L. Yinghua. 2006. "Modeling Goodwill for Banks: A Residual Income Approach with Empirical Tests," Contemporary Accounting Research. Spring, Volume 23 Iss. 1.

6. Bourne, J. H. 1888 "Goodwill," The Accountant, Sept. 22, 604.

7. _ _ California Code of Civil Procedure $\$ 1263.510(\mathrm{~b})$

8. Chauvin, K. W. and M. Hirschey 1994. "Goodwill, Profitability, and the Market Value of the Firm,” Journal of Accounting \& Public Policy. Summer, Vol. 13 Issue 2. 159-180

9. _ Compustat. Standard \& Poor's, a Division of the McGraw-Hill Companies, Inc. New York. 2007.

10. _Statement of Financial Accounting Concepts No. 6 Elements of Financial Statements," (SFAC 6) Financial Accounting Standards Board June 1985.

11. "Statement of Financial Accounting Standards No. 141 Business Combinations," (SFAS 141)

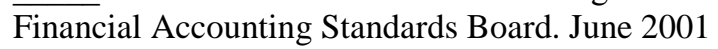

12. "Statement of Financial Accounting Standards No. 142 Goodwill and Other Intangible Assets," (SFAS 142) Financial Accounting Standards Board. June 2001

13. Fama, E. F., and K. R. FRENCH. "Industry costs of equity." Journal of Financial Economics 43 (1997), 153-193.

14. Fisher, I. 1906. The Nature of Capital and Income. New York: Reprints of Economic Classics, Augustus M. Kelley, Publisher.

15. Jennings, R., J. Robinson, R. B. Thompson II and L. Duvall. 1996 "The relationship between accounting goodwill numbers and equity values," Journal of Business Finance \& Accounting, June, Vol. 23 Iss. 4. 513-533

16. Johnson, T. L. and K. R. Petrone. 1998. "Is goodwill an asset?” Accounting Horizons Sept. 1998 Vol. 12 Iss. 3. 293-304.

17. Lander, G. and A. Reinstein. 2003. "Models to Measure Goodwill Impairment," International Advances in Economic Research, Aug. Vol. 9 Issue 3, p227-232

18. Massoud, M. F. and Raiborn, C. A. 2003. "Accounting for Goodwill: Are We Better Off?" Review of Business, Spring, Vol. 24 Issue 2, 26-32

19. McCarthy, M. G. and D. K. Schneider. 1995. "Market Perception of Goodwill: Some Empirical Evidence," Accounting \& Business Research, Winter, Vol. 26 Iss. 1. 69-81

20. Samuelson, R. A. 1996. "The concept of assets in accounting theory," Accounting Horizons. Sept. Vol.10 Iss.3. 147-157.

21. $\quad$ Schuetze, W. P. 1993. "What is an asset?" Accounting Horizons Sept. Vol 7. No.3. 66-70.

22. Vance, D. E. 2005. Raising Capital Springer, New York. 2005.

23. Wang, Z. 1995. "An Empirical Assessment of IASC's Proposed Goodwill Amortization Requirement," International Journal of Accounting, Vol. 30 Iss. 1, 37-47

24. Wang, Z. 1993. "An Empirical Evaluation of Goodwill Accounting," Journal of Applied Business Research, Vol. 9 No. 4. 127-133 


\section{APPENDIX A - INDUSTRY CLASSIFICATIONS}

This appendix is based on the Fama and French (1997) industry classifications plus the classification of the omitted SIC code of 3690 classified as electrical equipment, ElcEq.

\begin{tabular}{|c|c|c|c|c|c|}
\hline SIC range & Code & Industry & SIC range & Code & Industry \\
\hline 0100-0799 & Agric & Agriculture & $2850-2899$ & Chems & Chemicals \\
\hline 0800-0899 & BldMt & Construction Materials & $2900-2911$ & Enrgy & Petroleum and Natural Gas \\
\hline 0900-0999 & Toys & Recreational Products & $2950-2952$ & BldMt & Construction Materials \\
\hline $1000-1039$ & Mines & Nonmetallic Mining & $2990-2999$ & Enrgy & Petroleum and Natural Gas \\
\hline $1040-1049$ & Gold & Precious Metals & $3000-3000$ & Rubbr & Rubber and Plastic Products \\
\hline 1060-1099 & Mines & Nonmetallic Mining & $3010-3011$ & Autos & Automobiles and Trucks \\
\hline $1200-1299$ & Coal & Coal & $3020-3021$ & Clths & Apprel \\
\hline $1310-1389$ & Enrgy & Petroleum and Natural Gas & 3050-3099 & Rubbr & Rubber and Plastic Products \\
\hline $1400-1499$ & Mines & Nonmetallic Mining & $3100-3111$ & Clths & Apprel \\
\hline $1500-1549$ & Cnstr & Construction & $3130-3159$ & Clths & Apprel \\
\hline $1600-1699$ & Cnstr & Construction & $3160-3199$ & Hshld & Consumer Goods \\
\hline $1700-1799$ & Cnstr & Construction & $3200-3219$ & BldMt & Construction Materials \\
\hline $2000-2046$ & Food & Food Products & $3210-3221$ & Boxes & Shipping Containers \\
\hline $2047-2047$ & Hshld & Consumer Goods & $3229-3231$ & Hshld & Consumer Goods \\
\hline $2048-2048$ & Agric & Agriculture & $3240-3259$ & BldMt & Construction Materials \\
\hline $2050-2063$ & Food & Food Products & $3260-3260$ & Hshld & Consumer Goods \\
\hline 2064-2068 & Soda & Candy and Soda & $3261-3264$ & BldMt & Construction Materials \\
\hline $2070-2079$ & Food & Food Products & $3262-3263$ & Hshld & Consumer Goods \\
\hline $2080-2085$ & Beer & Alcoholic Beverages & $3269-3269$ & Hshld & Consumer Goods \\
\hline $2086-2087$ & Soda & Candy and Soda & $3270-3299$ & BldMt & Construction Materials \\
\hline 2090-2095 & Food & Food Products & $3300-3369$ & Steel & Steel Works, etc. \\
\hline 2096-2097 & Soda & Candy and Soda & 3390-3399 & Steel & Steel Works, etc. \\
\hline 2098-2099 & Food & Food Products & $3400-3400$ & FabPr & Fabricated Products \\
\hline $2100-2199$ & Smoke & Tobacco Products & $3410-3412$ & Boxes & Shipping Containers \\
\hline $2200-2295$ & Txtls & Textiles & $3420-3442$ & BldMt & Construction Materials \\
\hline $2296-2296$ & Autos & Automobiles and Trucks & $3443-3444$ & FabPr & Fabricated Products \\
\hline $2297-2299$ & Txtls & Textiles & $3446-3452$ & BldMt & Construction Materials \\
\hline $2300-2390$ & Clths & Apprel & $3460-3479$ & FabPr & Fabricated Products \\
\hline $2391-2392$ & Hshld & Consumer Goods & $3480-3489$ & Guns & Defense \\
\hline 2393-2395 & Txtls & Textiles & $3490-3499$ & BldMt & Construction Materials \\
\hline $2396-2396$ & Autos & Automobiles and Trucks & $3510-3536$ & Mach & Machinery \\
\hline $2397-2399$ & Txtls & Textiles & $3537-3537$ & Autos & Automobiles and Trucks \\
\hline $2400-2439$ & BldMt & Construction Materials & $3540-3569$ & Mach & Machinery \\
\hline $2440-2449$ & Boxes & Shipping Containers & $3570-3579$ & Comps & Computers \\
\hline $2450-2459$ & BldMt & Construction Materials & $3580-3599$ & Mach & Machinery \\
\hline $2490-2499$ & BldMt & Construction Materials & $3600-3621$ & ElcEq & Electrical Equipment \\
\hline $2510-2519$ & Hshld & Consumer Goods & $3622-3622$ & Chips & Electronic Equipment \\
\hline $2520-2549$ & Paper & Business Supplies & $3623-3629$ & ElcEq & Electrical Equipment \\
\hline $2590-2599$ & Hshld & Consumer Goods & $3630-3639$ & Hshld & Consumer Goods \\
\hline $2600-2639$ & Paper & Business Supplies & $3640-3646$ & ElcEq & Electrical Equipment \\
\hline $2640-2659$ & Boxes & Shipping Containers & $3647-3647$ & Autos & Automobiles and Trucks \\
\hline $2670-2699$ & Paper & Business Supplies & $3648-3649$ & ElcEq & Electrical Equipment \\
\hline $2700-2749$ & Books & Printing and Publishing & $3650-3652$ & Toys & Recreational Products \\
\hline $2750-2759$ & BusSv & Business Services & $3660-3660$ & ElcEq & Electrical Equipment \\
\hline $2760-2761$ & Paper & Business Supplies & $3661-3679$ & Chips & Electronic Equipment \\
\hline $2770-2799$ & Books & Printing and Publishing & $3680-3689$ & Comps & Computers \\
\hline $2800-2829$ & Chems & Chemicals & $3691-3692$ & ElcEq & Electrical Equipment \\
\hline $2830-2836$ & Drugs & Pharmaceutical Products & $3693-3693$ & MedEq & Medical Equipment \\
\hline $2840-2844$ & Hshld & Consumer Goods & $3694-3694$ & Autos & Automobiles and Trucks \\
\hline
\end{tabular}




\section{APPENDIX A - INDUSTRY CLASSIFICATIONS - CONTINUED}

\begin{tabular}{|c|c|c|}
\hline SIC range & Code & Industry \\
\hline $3695-3695$ & Comps & Computers \\
\hline $3690-3690$ & ElcEq & Electrical Equipment \\
\hline $3699-3699$ & ElcEq & Electrical Equipment \\
\hline $3700-3716$ & Autos & Automobiles and Trucks \\
\hline $3720-3729$ & Aero & Aircraft \\
\hline $3730-3731$ & Ships & Shipbuilding, Railroad Eq. \\
\hline $3732-3732$ & Toys & Recreational Products \\
\hline $3740-3743$ & Ships & Shipbuilding, Railroad Eq. \\
\hline $3750-3751$ & Hshld & Consumer Goods \\
\hline $3760-3769$ & Guns & Defense \\
\hline $3790-3792$ & Autos & Automobiles and Trucks \\
\hline $3795-3795$ & Guns & Defense \\
\hline 3799-3799 & Autos & Automobiles and Trucks \\
\hline $3800-3800$ & Hshld & Consumer Goods \\
\hline $3810-3810$ & Chips & Electronic Equipment \\
\hline $3811-3811$ & $\mathrm{LabEq}$ & Measuring and Control Eq. \\
\hline $3812-3812$ & Chips & Electronic Equipment \\
\hline $3820-3830$ & $\mathrm{LabEq}$ & Measuring and Control Eq. \\
\hline $3840-3851$ & MedEq & Medical Equipment \\
\hline 3860-3879 & Hshld & Consumer Goods \\
\hline $3900-3900$ & Misc & Miscellaneous \\
\hline 3910-3919 & Hshld & Consumer Goods \\
\hline 3930-3949 & Toys & Recreational Products \\
\hline $3950-3955$ & Paper & Business Supplies \\
\hline 3960-3961 & Hshld & Consumer Goods \\
\hline $3965-3965$ & Clths & Apprel \\
\hline 3990-3990 & Misc & Miscellaneous \\
\hline 3991-3991 & Hshld & Consumer Goods \\
\hline 3993-3993 & BusSv & Business Services \\
\hline 3995-3995 & Hshld & Consumer Goods \\
\hline 3996-3996 & BldMt & Construction Materials \\
\hline 3999-3999 & Misc & Miscellaneous \\
\hline $4000-4099$ & Trans & Transportation \\
\hline $4100-4199$ & Trans & Transportation \\
\hline $4200-4299$ & Trans & Transportation \\
\hline $4400-4499$ & Trans & Transportation \\
\hline $4500-4599$ & Trans & Transportation \\
\hline $4600-4699$ & Trans & Transportation \\
\hline $4700-4799$ & Trans & Transportation \\
\hline $4800-4899$ & Telcm & Telecommunications \\
\hline 4900-4999 & Util & Utilities \\
\hline $5000-5099$ & Whlsl & Wholesale \\
\hline $5100-5199$ & Whlsl & Wholesale \\
\hline $5200-5299$ & Retail & Retail \\
\hline $5300-5399$ & Retail & Retail \\
\hline $5400-5499$ & Retail & Retail \\
\hline $5500-5599$ & Retail & Retail \\
\hline $5600-5699$ & Retail & Retail \\
\hline $5700-5736$ & Retail & Retail \\
\hline
\end{tabular}

\begin{tabular}{|c|c|c|}
\hline SIC range & Code & Industry \\
\hline $5800-5813$ & Meals & Restaurants, Hotel, Motel \\
\hline $5890-5890$ & Meals & Restaurants, Hotel, Motel \\
\hline $5900-5999$ & Retail & Retail \\
\hline $6000-6099$ & Banks & Banking \\
\hline 6100-6199 & Banks & Banking \\
\hline $6200-6299$ & Fin & Trading \\
\hline $6300-6399$ & Insur & Insurance \\
\hline $6400-6411$ & Insur & Insurance \\
\hline $6500-6553$ & RlEst & Real Estate \\
\hline $6700-6799$ & Fin & Trading \\
\hline 7000-7019 & Meals & Restaurants, Hotel, Motel \\
\hline $7020-7021$ & PerSv & Personal Services \\
\hline $7030-7039$ & PerSv & Personal Services \\
\hline $7040-7049$ & Meals & Restaurants, Hotel, Motel \\
\hline $7200-7212$ & PerSv & Personal Services \\
\hline $7213-7213$ & Meals & Restaurants, Hotel, Motel \\
\hline $7215-7299$ & PerSv & Personal Services \\
\hline $7300-7372$ & BusSv & Business Services \\
\hline $7373-7373$ & Comps & Computers \\
\hline 7374-7394 & BusSv & Business Services \\
\hline 7395-7395 & PerSv & Personal Services \\
\hline 7397-7397 & BusSv & Business Services \\
\hline 7399-7399 & BusSv & Business Services \\
\hline $7500-7500$ & PerSv & Personal Services \\
\hline $7510-7519$ & BusSv & Business Services \\
\hline $7520-7549$ & PerSv & Personal Services \\
\hline $7600-7699$ & PerSv & Personal Services \\
\hline $7800-7841$ & Fun & Entertainment \\
\hline $7900-7999$ & Fun & Entertainment \\
\hline $8000-8099$ & Hlth & Healthcare \\
\hline $8100-8199$ & PerSv & Personal Services \\
\hline $8200-8299$ & PerSv & Personal Services \\
\hline $8300-8399$ & PerSv & Personal Services \\
\hline $8400-8499$ & PerSv & Personal Services \\
\hline $8600-8699$ & PerSv & Personal Services \\
\hline $8700-8748$ & BusSv & Business Services \\
\hline $8800-8899$ & PerSv & Personal Services \\
\hline 8900-8999 & BusSv & Business Services \\
\hline 9900-9999 & Misc & Miscellaneous \\
\hline $5800-5813$ & Meals & Restaurants, Hotel, Motel \\
\hline $5890-5890$ & Meals & Restaurants, Hotel, Motel \\
\hline 5900-5999 & Retail & Retail \\
\hline 6000-6099 & Banks & Banking \\
\hline $6100-6199$ & Banks & Banking \\
\hline $6200-6299$ & Fin & Trading \\
\hline $6300-6399$ & Insur & Insurance \\
\hline $6400-6411$ & Insur & Insurance \\
\hline $6500-6553$ & RlEst & Real Estate \\
\hline $6700-6799$ & Fin & Trading \\
\hline
\end{tabular}




\section{NOTES}

